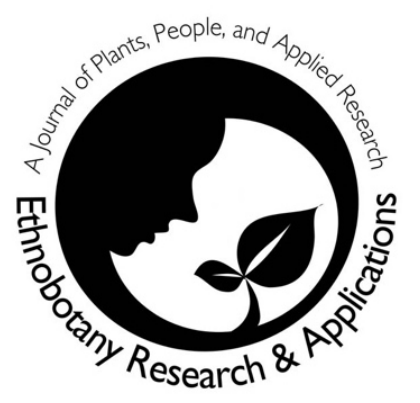

\title{
Socio-economic value and ethnobotanical study of Moroccan wild Leopoldia comosa L. Parl. bulbs
}

Mohamed Boulfia, Fatima Lamchouri, Nacima Lachkar, Abdelmajid Khabbach, Abdelouahab Zalaghi and Hamid Toufik

\begin{abstract}
Background: Leopoldia comosa (L.) Parl. (Syn. Muscari comosum (L.) Mill.), or Toupee Muscari is a perennial in the Asparagaceae growing in Morocco and the Mediterranean area. In the Moroccan Rif mountains, it is found in significant quantities. In the spring, large quantities of the plant are marketed weekly in the souks (weekly markets) for export abroad, mainly to Italy. Little research has been conducted on the species and its trade-in Morocco or other southern Mediterranean countries. Given the lack of information about this plant, this study aims to reveal for the first time the socio-economic value and ethnobotanical data of this species in Morocco.
\end{abstract}

Methods: Socio-economic and ethnobotanical data were collected from March 2018 to May 2019 by direct interviews with vendors and wholesalers of the plant using a designated questionnaire in seven municipalities (Aknoul, Meknassa Acharqia, Bab Marzouka, Bni Lent, Ras-El-Ma, Meknassa Al Gharbia, Oued Amlil) of the Province of TazaMorocco.

Results: The results of the surveys revealed that Moroccan $L$. comosa bulbs are commonly known as "Bassila," and represent an important source of income for vendors and wholesalers. The profit varies from $7 \mathrm{MAD} / 0.64 €$ per $\mathrm{kg}$ of fresh bulb to 3 MAD / $0.27 €$ per $\mathrm{kg}$ of fresh bulb for vendors and wholesalers respectively. Locally, the bulbs are used in the treatment of dermatological affections and digestive disorders.

Conclusions: L. comosa bulbs represent an important source of income for the population and a promising source of bioactive molecules to treat different diseases.
Keywords: Income; Interviews; Questionnaire; Wholesalers; Province of Taza - Morocco.

\section{Correspondence}

Mohamed Boulfia, Fatima Lamchouri*, Nacima Lachkar, Abdelmajid Khabbach, Abdelouahab Zalaghi, Hamid Toufik

Laboratory of Natural Substances, Pharmacology, Environment, Modelling, Health \& Quality of Life (SNAMOPEQ), Polydisciplinary Faculty of Taza, Sidi Mohamed Ben Abdellah University of Fez, B.P.: 1223 Taza-Gare, Taza, Morocco.

*Corresponding Author:

fatima.lamchouri@usmba.ac.ma, fatima.lamchouri@gmail.com

\section{Ethnobotany Research \& Applications} 20:05 (2021)

\begin{abstract}
Résumé
Contexte: Leopoldia comosa (L.) Parl. (Syn. Muscari comosum (L.) Mill.), ou Muscari à toupet est une plante vivace de la famille des Asparagacées qui pousse au Maroc et dans la zone méditerranéenne, on la trouve dans les régions du Rif avec des quantités importantes. Au printemps, de grandes quantités de la plante sont commercialisées chaque semaine dans les souks (marché hebdomadaire) pour une exportation à l'étranger, principalement vers I'Italie mais aucune étude scientifique n'a été menée sur celle-ci ni au Maroc ni dans les pays méditerranéens sud. Vu le manque d'informations sur cette plante, la présente étude vise à révéler pour la première fois la valeur socio-économique et les
\end{abstract}


données ethnobotaniques des bulbes de Leopoldia comosa L. Marocaine.

Méthodes: Les données socio-économiques et ethnobotaniques ont été recueillies de Mars 2018 à Mai 2019 par des interviews face à face avec les exploitants et les grossistes de la plante en utilisant une fiche questionnaire dans sept communes (Aknoul, Meknassa Acharqia, Bab Marzouka, Bni Lent, Ras-El-Ma, Meknassa Al Gharbia, Oued Amlil) de la Province de Taza - Maroc.

Résultats: Les résultats des enquêtes ont révélé que Leopoldia comosa marocaine communément appelée «Bassila» constitue une source importante de revenus pour les exploitants et aussi pour les grossistes et que ces revenus varient de 7 MAD / $0,64 €$ par $\mathrm{kg}$ de bulbe frais à 3 MAD / 0,27 € par kg de bulbe frais pour les vendeurs et les grossistes respectivement. Localement, les bulbes sont utilisés dans le traitement des affections dermatologiques et des troubles digestifs.

Conclusion: Leopoldia comosa représente une source importante de revenus pour la population et une source prometteuse des molécules bioactives pour traiter différentes maladies.

Mots-clés: Revenu ; Interviews ; Questionnaire ; Grossistes ; Province de Taza - Maroc.

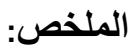

السياق: Leopoldia comosa (L.) Parl. مرادف Muscari المبن أو Muscomosum (L.) Mill.

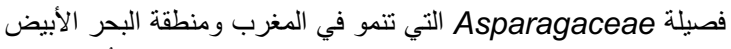

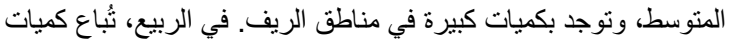

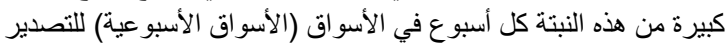

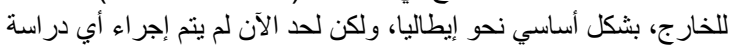

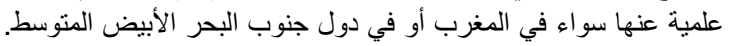

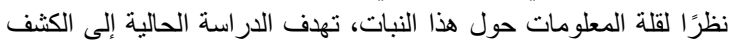

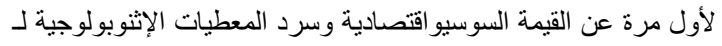
Leopoldia comosa

الأساليب: تم جمع البيانات السوسيواقتصادية والإثتوبولوجية من مارس

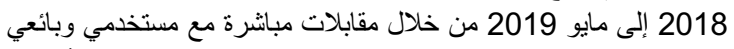

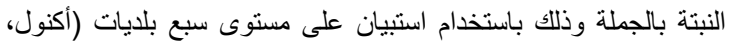

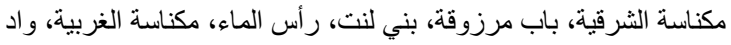
امليل) تنتمي إلى إقليم تازة - المغرب.

النتائج: كثفت نتائج الاسنطلاعات أن Leopoldia comosa المغربية

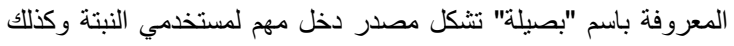

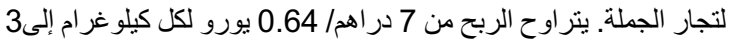

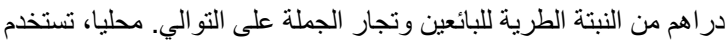

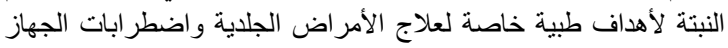
الهضمي.

الخلاصة: تمثل Leopoldia comosa مورد دخل مهم للسكان المحليين ومصدرًا مهما للجزيئات النشطة بيولوجيًا لعلاج الأمر اض المختلفة.

$$
\text { المغرب. المفاتيح : الدخل ؛ مقابلات؛ استبيان؛ تجار الجملة؛ إقليم تازة - }
$$

\section{Background}

Leopoldia comosa L. of the Asparagaceae family is a wild, perennial plant that regenerates from a bulb and is native to the Mediterranean region (Casoria et al. 1999, Casacchia et al. 2017). In Morocco, the plant is widely distributed, commonly known as "Bassila" with geographic dominance in the Rif and Middle Atlas regions (Valdés et al. 2002). During the spring period, large quantities of the plant are transported weekly in the souks (weekly market) for marketing and export abroad, mainly to the Italian market (Khabbach et al. 2012).

According to our bibliographical research, no scientific studies have been carried out on Leopoldia comosa in Morocco or other southern Mediterranean countries. The only works we identified were from Italy where Casoria et al. (1999) reported L. comosa as one of the wild plants most used in the food habits of the population of southern Italy and that the bulbs have diuretic and astringent proprieties (Casoria et al. 1999). In 2012, Bonasia and collaborators reported $L$. comosa as is part of the diet and is used in traditional medicine in the treatment of gastronomic problems in the South. In the past in Italy, the bulbs were mainly taken from wild populations, but nowadays, the expansion of agriculture and the increased costs in harvesting have favored the import of the bulbs, mainly from North Africa and especially from Morocco and Tunisia (Bonasia et al. 2012).

Today, there is a progressive awareness of the medical and economic potential of natural resources. Morocco and more particularly the province of Taza is characterized by a rich floristic and natural phytodiversity, which makes the province a subsistence economy zone through the commercialization of some products such as Origanum spp, Ziziphus spp, and Capparis spinosa L. (Khabbach et al. 2012). Within the framework of the valorization of the plants of origin of Taza, we have chosen for the present study, Leopoldia comosa, a very abundant plant in our study area but few studies on this plant.

This study aims to assess for the first time the socioeconomic value and ethnobotanical data of this plant using a questionnaire which contains two parts, the first deals with the medicinal aspect of the plant such as the part used, method of use and preparations, nutritional value, the dose used and the main diseases treated and the second the socio-economic aspect which was concerning the sale price in $\mathrm{kg}$, the quantity of the plant sold per year, the quantity of the 
plant harvested per day or per week, number of employees per household and total income per year.

\section{Material and Methods}

Socio-economic and Ethnobotanical Data Collection

Socio-economic and ethnobotanical data of Leopoldia comosa (L.) Parl. (Fig. 1) were collected from March 2018 to May 2019 in seven municipalities (Aknoul, Meknassa Acharqia, Bab Marzouka, Bni Lent, Ras-El-Ma, Meknassa Al Gharbia, Oued Amlil) of the Province of Taza (Geographical coordinates: N 34¹3'56.0" W $3^{\circ} 59^{\prime} 50.4^{\prime \prime}$, Altitude $421 \mathrm{~m}$ ) which is located in the North East of Morocco (Fig. 2). The Province has 38 municipalities and is bordered to the North by the Provinces of Al Hoceima and Driouch, to the South by the Province of Sefrou, and to the West by the Province of Taounate. At the northernmost tip of the Middle Atlas Mountains, close to Taza, extends the Tazekka National Park, gazetteer in 1950, and extending over a length of $50 \mathrm{~km}$ and a width of 15 $\mathrm{km}$ (Fig. 2). The choice of study stations was made following the recommendations of the population, regarding the abundance of this plant in these municipalities.

The study was conducted in the form of questionnaire-guided interviews (Appendix 1) consisting of both closed and open-ended questions which we have prepared regarding previously conducted studies and which aims to collect information on the interviewees (age, sex, level of education, ethnic group, profession, family situation); vegetable species and/or plant (vernacular names, type of plant: wild or cultivated, harvest season, etc); medicinal aspect of the plant such as the part used, method of use and preparations, nutritional value, the dose used and the main diseases treated (Heinrich et al. 2009, Zahoor et al. 2017). Information about socio-economic value was concerning the sale price in $\mathrm{kg}$ of fresh bulb of $L$. comosa, the quantity of the plant sold per year, the quantity of the plant harvested per day or per week as presented in previous works (Gharnit et al. 2006, Baydoun et al. 2017), number of employees per household, and total income per year (Appendix 1).

As there is a diversity of local dialects in the study area: tribes (Ghiata, Tssoul, Branés) who speak the Moroccan Arabic dialect called "Darija" or Amazigh who speak one of the 3 Amazigh dialects ("Tamazight", "Tarifit" and "Tachelhit or Tasousit"). The interviews were conducted through a local translator knowledgeable in both Arabic or Amazigh dialects for respondents who cannot use either the Arabic or French survey form.
Respondents were informed of the objectives of the study and the fact that the information collected will be posted for scientific and non-commercial purposes and thus agreed to participate in the survey.

\section{Plant Material}

Leopoldia comosa (L.) Parl. (Fig. 1) were harvested in the province of Taza (Morocco) (Fig. 2) during the spring, March 2018, and the plant was identified by Dr. Abdelmajid Khabbach, the botanist of the Laboratory of Natural Substances, Pharmacology, Environment, Modelling, Health \& Quality of Life (SNAMOPEQ), Polydisciplinary Faculty of Taza (FPT), Sidi Mohamed Ben Abdellah University of Fez, Morocco. A voucher specimen was deposited in the herbarium under the code SA 2018/05.

\section{Statistical analysis}

Descriptive statistics were used to summarize the data. Frequencies were expressed as the number and percentage of vendors.

\section{Results}

Socio-economic and Ethnobotanical Data of Leopoldia comosa bulbs

Socio-demographic Characteristics of the Respondents

During this study, a total of 100 people were interviewed in seven municipalities (Aknoul, Meknassa Acharqia, Bab Marzouka, Bni Lent, RasEl-Ma, Meknassa Al Gharbia, Oued Amlil) of the Province of Taza, Morocco chosen according to the abundance of the plant in these municipalities. The interviewees included 85 vendors and 15 wholesalers or "Jemmalla" (Table 1). Demographic characteristics of the respondents were determined and recorded through face-to-face interviews. All the interviewees were men because we have not met any woman who participates in the marketing of this plant, with an average age of 32 years, and with a primary education level of $38 \%$, secondary education of $39 \%$, and $23 \%$ for illiterate people.

The number of respondents per municipality depends on the quantity of the plant produced in each municipality and the demand for the plant by the wholesalers or "Jemmalla" of that plant.

Socio-economic Value of Leopoldia comosa bulbs To assess the socio-economic value of $L$. comosa, we conducted a survey with local vendors and wholesalers during the plant's harvest period. Interviews focused on the selling price of the raw material in kilogram $(\mathrm{kg})$, the quantity of the plant sold per week, and the total revenue per week. Table 2 shows the results of the economic value of $L$. comosa 


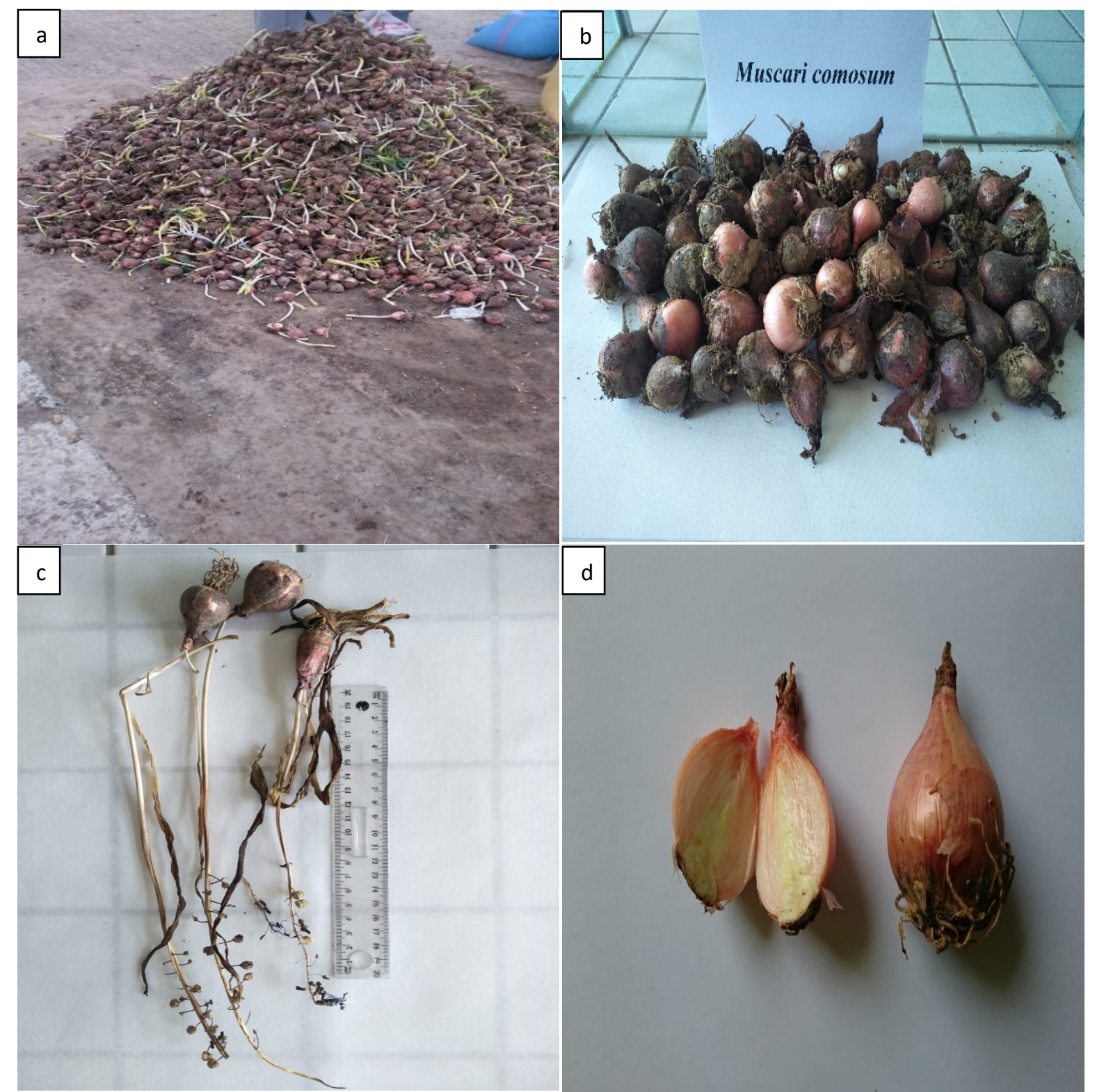

Figure 1. a. Leopoldia comosa L. Parl in the souk (weekly market); b. Bulbs dried at the SNAMOPEQ Laboratory, FPT, USMBA; c. Herbarium sample; d. Peeled bulbs in SNAMOPEQ Laboratory. Photos are taken in March 2018 in Taza, Morocco (Geographical coordinates: N 34 $13^{\prime} 56.0^{\prime \prime}$ W 359'50.4", Altitude 421 m).

Table 1. Sociodemographic characteristics of respondents $(n=100)$ in the Province of Taza Morocco.

\begin{tabular}{|l|l|}
\hline Characteristics & Frequency \\
\hline Gender & \\
Male & 100 \\
Female & 0 \\
\hline Educational level & \\
Illiterate & 23 \\
Primary school & 38 \\
Secondary school & 39 \\
\hline Age & \\
17-39 & 77 \\
Over 40 & 23 \\
\hline
\end{tabular}

In this regard, our study showed that the quantity of the plant harvested varies according to age; a young person can harvest up to 100 kilograms per week, given the physical effort of harvesting, and this quantity also varies according to the wholesalers and vendors of the plant in the souks. Wholesalers or "Jemmala" buy the plant in the souks and douars and trade it through intermediaries from Taza, towards mainly the city of Oued Zem which is located in the center of Morocco, roughly $300 \mathrm{~km}$ from the place of origin. In Oued Zem, small-scale factories carry out the cleaning of the residues of soil and sand that surround the bulbs, the sorting of the bulbs that are going to be peeled, and the separation of the bulb from the stem, and finally the packaging for export abroad, mainly to Italy. 
The standardization of the price has been done by converting the price in dirham for one kilogram to Euro $(€)$ according to international standards (www.xe.com). The unit price of $L$. comosa was estimated at 7 MAD per $\mathrm{kg}(0.697 € / \mathrm{kg})$ for vendors and 10 MAD per $\mathrm{kg}(0.91 € / \mathrm{kg})$ for wholesalers. According to the surveys, the evolution of the market depends on the rate of annual precipitation; if the rate of precipitation is higher, so the production of the plant also is higher, consequentially the price selling of $L$. comosa bulbs decrease.

According to Table 2, the total profit varies from 413 MAD / $38 €$ per collected quantity/week to 2860.5 MAD / $263.16 €$ per selling quantity/week for vendors and wholesalers respectively.

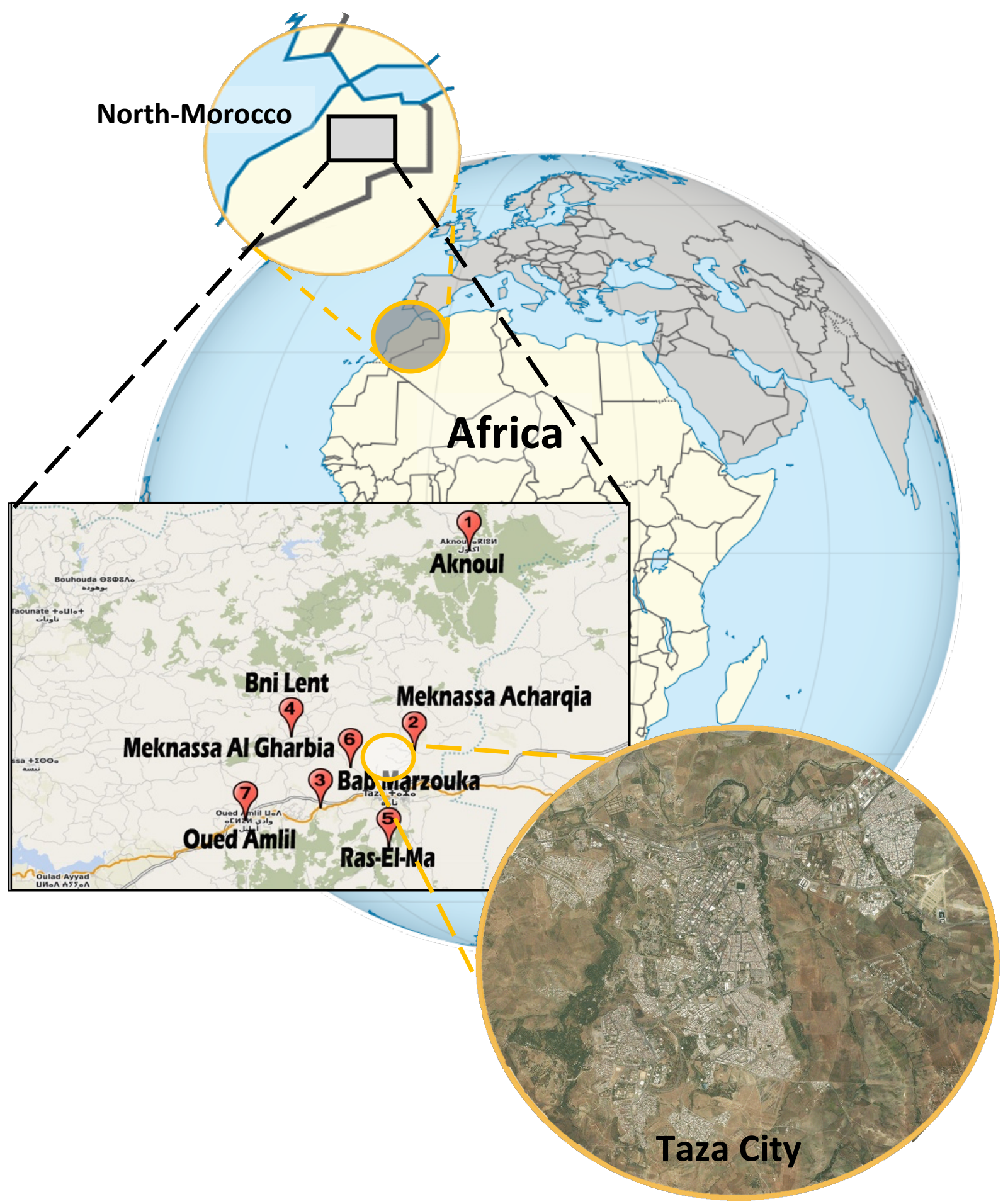

Figure 2. Geographic representation of the area study and map depicting the municipalities of the survey in the Province of Taza - Morocco (Basemap source). 
Table 2. Socio-economic data of Leopoldia comosa bulbs in the Province of Taza - Morocco.

\begin{tabular}{|l|l|l|}
\hline Economic value & $\begin{array}{l}\text { Vendors } \\
\text { (Collectors) }\end{array}$ & Wholesalers \\
\hline Average quantity sold per week in $\mathrm{kg}$ & 59 & 953.5 \\
\hline Selling price per $\mathrm{kg}$ & $7 \mathrm{MAD} / 0.64 €$ & $10 \mathrm{MAD} / 0.92 €$ \\
\hline Cost price per $\mathrm{kg}$ & 0 & $7 \mathrm{MAD}$ \\
\hline Cost price per week & 0 & $953.5 \mathrm{~kg}$ * $7 \mathrm{MAD}=$ \\
& $6674.5 \mathrm{MAD} / 614.05 €$ \\
\hline Total profit per week & $\begin{array}{l}59 \mathrm{~kg} * 7 \mathrm{MAD}= \\
413 \mathrm{MAD} / 38 €\end{array}$ & $\begin{array}{l}\left(953.5^{\star} 10\right)-\left(953.5^{\star} 7\right) \\
2860.5 \mathrm{MAD} / 263.16 €\end{array}$ \\
\hline
\end{tabular}

- $\quad$ Kg: Kilogram; MAD: Moroccan dirham; $€$ : Euro.

- Values in the table are expressed by calculating the average for each parameter.

Ethnobotanical Data of Leopoldia comosa bulbs The abundant trade of $L$. comosa in the local markets of the Province of Taza prompted us to research the medicinal value of this plant-based on a questionnaire which includes information on the part of the plant used, the method of preparation, and the diseases treated.

All respondents $(n=100)$ reported the economic value of $L$. comosa (100\%). $33 \%$ of the population surveyed revealed the therapeutic effect in addition to the economic value of the plant and $10 \%$ mentioned that the gel of $L$. comosa bulbs is used in sticking.

The part of the plant used is the bulb in the form of poultice and infusion to treat dermatological affections and digestive disorders respectively.

$24 \%$ of the population uses the plant to treat dermatological affection and $13 \%$ for digestive disorders.

\section{Discussion}

Socio-economic and Ethnobotanical Data of Leopoldia comosa bulbs

The results of the present study highlight the socioeconomic value and ascribed medicinal properties of the plant in Morocco. The results of the surveys reveal that $L$. comosa bulb is used to treat dermatological affections and digestive tract disorders. These results are in agreement with Pieroni et al. (2002) which reported that $L$. comosa bulb is used in Italy in the treatment of gastronomic problems. Casoria et al. (1999) reported that $L$. comosa bulb has a diuretic and astringent effect, and also a veterinary use as a revulsive if bulbs are mixed with pepper.

The subsistence economy in the study area is associated, among other things, with the exploitation of wild plants such as Origanum spp, Ziziphus spp, and Capparis spinosa L., whose selling prices vary from 14.4 MAD/kg, $17 \mathrm{MAD} / \mathrm{kg}$ and $14.8 \mathrm{MAD} / \mathrm{kg}$ respectively (Khabbach et al. 2012), and Chamaerops humilis L. var. argentea André which is an important source of revenue through the sale of the palm heart (43.22 €/week/exploiter), and marketing of artisanal products (Doum baskets: 6.2 $€ /$ week/maker). (Lachkar et al. 2020), and L. comosa are species that constitute an important source of income for rural families in the study area. Commercialization of some products of local phytodiversity is often limited to the harvest period, i.e. the growing season.

$L$. comosa is a spontaneous plant in the region of Taza, harvested from January to May each year. During this period, Large quantities ranging from 500 $\mathrm{kg}$ to $3000 \mathrm{~kg}$ of fresh $L$. comosa bulb are offered on sale every week in the souks. The study carried out by Bonasia and his collaborators in Italy concurs with the information we found and which indicated that the import of $L$. comosa has increased particularly from Morocco and Tunisia due to the intensive use of bulbs in Italy (Bonasia et al. 2012).

The average quantity of the plant purchased in Morocco in the study area by wholesalers each week is about $953.5 \mathrm{~kg}$ of fresh bulbs. Therefore, this quantity constitutes a total profit of 2860.5 MAD / $263.16 €$.

Among the information we gathered during our investigation is that the plant is intended for export and more specifically to Italy, as it is included in their diet after pre-treatment and preparation in factories in Oued Zem city (Morocco). This result explains what we found in the work published by Casoria et al. (1999) that the food use of bulbs has a long history that can be traced back to the Egyptians, Greeks, and other Mediterranean peoples.

According to our survey, we can say that $L$. comosa is an important source of income for vendors and also for wholesalers and that the profit varies from 7 
MAD / $0.64 €$ per $\mathrm{kg}$ of fresh bulb to 3 MAD / $0.27 €$ per $\mathrm{kg}$ of fresh bulb for vendors and wholesalers respectively. Compared to another study conducted in the same study area, Lachkar et al. (2020) showed that Chamaerops humilis L. var. argentea André is an important source of income for the population of the Province of Taza through the sale of the palm heart (43.22 $€ /$ week/exploiter), and the marketing of artisanal products (Doum baskets: 6.2 $€ /$ week/maker).

Although, women are active storekeepers, street and market vendors and play an important role in commerce around the world. In our study, women are not allowed to participate in the marketing of $L$. comosa, this can be explained by the traditional customs in the study area, where women are much more involved in domestic chores and where women probably prefer to work in women's associations or cooperatives, which are also channels and means of marketing the plant's bulbs, rather than going directly to the souks.

It is important to notify that in the municipalities "Oued Amlil" and "Bni Lent" small quantities of $L$. comosa are offered for sale in the souks, even if in these two municipalities the plant is very abundant, because the harvest period coincides with the olive harvesting season and the population of these communes is not yet conscious of the economic value of the $L$. comosa bulbs and prefers to harvest the olives even though their price (4 MAD/Kg / 0.398 $€ / \mathrm{Kg}$ ) is lower than that of $L$. comosa bulbs (7 MAD/Kg / $0.697 € / \mathrm{Kg}$ ) and also because the plant requires special experience during harvesting to ensure that the bulbs are not damaged and a great deal of physical effort.

\section{Conclusions}

These studies, undertaken for the first time in Morocco, allowed us to document and describe the socio-economic value and the ethnobotanical data of Leopoldia comosa L., a spontaneous plant of the Taza region which is characterized by a high production of this plant. The survey conducted among vendors and wholesalers of the plant allowed us to draw several conclusions: all respondents $(n=100)$ are looking for Leopoldia comosa for a monetary purpose; $33 \%$ of the population surveyed raised the medicinal value of the plant, and that the bulb of $L$. comosa is used in the treatment of dermatological affections and digestive disorders. Indeed, L. comosa is an important source of income for vendors and also for wholesalers and its profit varies from $7 \mathrm{MAD} / 0.64 €$ per $\mathrm{kg}$ of fresh bulb to 3 MAD / $0.27 €$ per $\mathrm{kg}$ of fresh bulb for vendors and wholesalers respectively. Wholesalers buy the plant in the souks and trade it through intermediaries from
Taza, towards mainly the city of Oued Zem which is located in the center of Morocco, roughly $300 \mathrm{~km}$ from the place of origin (Morocco) where there are points of export abroad, especially to Italy.

This study highlights the economic importance of $L$. comosa as a medicinal plant and food for export to Italy as it is included in their diet.

Our results of the socio-economic and ethnobotanical surveys of the plant are encouraged and we are continuing to analyze the composition of the plant and explore its other biological and pharmacological properties.

\section{Declarations}

List of abbreviations: Not applicable.

Ethics approval and consent to participate: All respondents were well informed of the objectives of the study, have been well informed, the confidentiality of their participation, and the data provided and the right to refuse to participate and withdraw at any time.

Consent for publication: Not applicable.

Availability of data and materials: The data was not deposited in public repositories.

Conflicts of interest: There is no conflict of interest. Funding sources: This research did not receive any specific grant from funding agencies in the public, commercial, or not-for-profit sectors.

Author's contributions: MB: Performed experimental studies and field studies, data collection and analysis and manuscript preparation. FL: Designed the experiments, consistent guidance, analyzed the data, manuscript preparation and review and edited the final version and submitted it for publication. NL: Contributed to experimental and field studies. AK: Contributed to botanical studies. AZ: Contributed to data analysis. HT: Designed the experiments, provided consistent guidance and manuscript preparation and review. All authors read, approved and reviewed the manuscript.

\section{Acknowledgements}

The authors are extremely thankful to the local informants of the study area for their co-operation and knowledge sharing. Our sincere appreciation goes to all the people who helped us during the research work.

\section{Literature Cited}

Baydoun SA, Kanj D, Raafat K, Aboul Ela M, Chalak L, Arnold-Apostolides N. 2017. Ethnobotanical and Economic Importance of Wild Plant Species of Jabal Moussa Bioreserve, Lebanon. Journal of Ecosystem and Ecography 7:245. doi: 10.4172/21577625.1000245. 
Basemap source: https://www.cleanpng.com/pngglobe-earth-world-rwanda-map-yellow-globe5580809/preview.html

Bonasia A, Conversa G, Lazzizera C, La Rotonda P, Elia A. 2012. Weed control in lampascione-Muscari comosum (L.) Mill. Crop Protection 36:65-72. doi:10.1016/j.cropro.2012.02.001.

Casacchia T, Sofo A, Casaburi I, Marrelli M, Conforti F, Statti GA. 2017. Antioxidant, enzyme-inhibitory and antitumor activity of the wild dietary plant Muscari comosum (L.) Mill. International Journal of Plant Biology.

8(1)). doi:https://doi.org/10.4081/pb.2017.6895

Casoria P, Menale B, Muoio R. 1999. Muscari comosum, Liliaceae, in the Food Habits of South Italy. Economic Botany 53:113-115.

Gharnit N, El Mtili N, Ennabili A, Sayah F. 2006. Importance socio-économique du caroubier (Ceratonia siliqua L.) dans la province de Chefchaouen (Nord-ouest du Maroc). Journal de Botanique de la Société Botanique de France 33:4348.

Heinrich M, Edwards S, Moerman DE, Leonti M. 2009. Ethnopharmacological field studies: a critical assessment of their conceptual basis and methods. Journal of Ethnopharmacology 124:1-17. https://doi.org/10.1016/j.jep.2009.03.043

Khabbach A, Libiad M, Ennabili A. 2012. Production and merchandising of plant resources from the province of Taza (North of Morocco). Revue AFN Maroc. doi:10.6084/m9.figshare.12941888.v1

Lachkar N, Lamchouri F, Toufik H. 2020. Socioeconomic position of Chamaerops humilis L. var. argentea Andre in the province of Taza (North East Morocco) and impact of the new Moroccan law $n^{\circ} 77-$ 15 (Moroccan Official Bulletin $\mathrm{N}^{\circ}$ 6422) on the preservation of the environment. Ethnobotany Research \& Applications 20:32.

Pieroni A. 2000. Medicinal plants and food medicines in the folk traditions of the upper Lucca Province, Italy. Journal of Ethnopharmacology 70:235-273. https://doi.org/10.1016/S0378-8741(99)00207-X.

Pieroni A, Janiak V, Durr CM, Ludeke S, Trachsel E, Heinrich M. 2002. In vitro Antioxidant Activity of NonCultivated Vegetables of Ethnic Albanians in Southern Italy. Phytotherapy Research 16:467-473. doi:10.1002/ptr.1243.

Valdés B, Rejdali M, Achhal EL Kadmiri A, Jury JL, Montserrat JM. 2002. Checklist of vascular plants of $\mathrm{N}$ Morocco with identification keys. Editions CSIC, Madrid.

Zahoor M, Yousaf Z, Aqsa T, Haroon M, Saleh N, Aftab A, Javed S, Qadeer M, Ramazan H. 2017. An ethnopharmacological evaluation of Navapind and Shahpur Virkanin district Sheikupura, Pakistan for their herbal medicines. Journal of Ethnobiology and
Ethnomedicine 13:27. doi:10.1186/s13002-0170151-1. 


\section{Appendix 1}

\section{Questionnaire form}

Record number: ...

- Date.

- City / Village / Douar.

- Altitude

- Author.

\section{I- Informant or Interviewee:}

1- Age:

2- Gender: Male $\square$ Female $\square$

3- Marital Status: Single $\square$ Married $\square$

4- Ethnicity.

5- Level of education: Illiterates $\square$ Primary $\square$ Secondary $\square$ Academic

6- Profession: Herbalist $\square$ Cultivator $\square$ Tradipraticians $\square$ Nomad $\square$ Others $\square$

\section{II- Vegetable species and/or Plant:}

7. Vernacular names:

8- Scientific name:

9- Type of plant:

Wild $\square$ Cultivated $\square$

10- Harvest season:

11- Place of harvest:
$\square$ Watercourses
$\square$ Mountain
$\square$ Pond
$\square$ Lakes
$\square$ Others

\section{III- Medicinal aspect:}

12- Plant uses:

$\square$ Therapeutic

$\square$ Cosmetic

$\square$ Human food

$\square$ Fence

$\square$ Firewood

$\square$ Animal feed

$\square$ Others:

13- Used part: Stem $\square$ Flowers $\square$ Fruit $\square$ Seed $\square$ Bark $\square$ Rhizome $\square$ Bulb $\square$ Leaves $\square$ whole plant $\square$ Other combinations $\square$ :

14- Form of employment:

Tisane $\square$ Powder $\square$ Essential oils $\square$ Oily oils $\square$ Extract (tincture, solution, capsule) $\square$ Others $\square$

15- Mode of preparation: 
Infusion $\square$ Decoction $\square$ Maceration $\square$ Poultice $\square$ Kneading $\square$ Softening $\square$ Others

16- Mode of administration: Oral $\square$ Massage $\square$ Rinsing $\square$ Brushing $\square$ Others $\square$

17- Dose used:

Pinch $\square$ Handle $\square$ Spoon $\square$

Others $\square$

18- Plants and/or other substances:

$\square$ None $\square$ Yes

If Yes, which ones?

Notes on preparation:

19. Type of disease:

- Dermatological affections $\square$

- Digestive tract disorders $\square$

- Respiratory affections

- Gland disorders $\square$

- Diseases of the cardiovascular system $\square$

- Gastro-intestinal tract annexes $\square$

- Genitourinary affections $\square$

- Neurological Affections $\square$

-Others.

20- Toxicity:

IV-Socio-economic data of Leopoldia comosa $\mathrm{L}$.

21. Number or quantity of the plant harvested per day or per week:

22. Number or quantity of the plant deplaned per year:

23. Raw material selling price per $\mathrm{kg}$ :

24. Types of customers:

25. Request by customers:

Large $\square$ Medium $\square$ Low $\square$ Others:

26. Types of employees:

Men $\square$ Women $\square$ Children $\square$ Indigenous $\square$ Others $\square$

27. Number of employees in each house:

28. Direct Employment: 
Full-time $\square$ Part-time $\square$ Other $\square$

29. Working period:

30. Number or quantity of the plant sold per year:

31. Total income per week:

32. Cost price:

33. Types of marketing:

Associations/cooperatives $\square$ Intermediaries $\square$ Souks $\square$ Other $\square$

34. Market evolution:

35. Obstacles that you encounter:

36. Supplementary information: 
Appendix 2 / Annexe 2

\section{Fiche questionnaire}

Numéro de fiche:

- Date.

- Ville/Village/Douar.

- Altitude

- Auteur.

\section{I- Informateur ou Interviewé :}

1- Age :

2- Sexe : Masculin $\square$ Féminin $\square$

3- Situation familiale : Célibataire $\square$ Marié $\square$

4- Ethnie.

5- Niveau scolaire : Néant $\square$ Primaire $\square$ Secondaire $\square$ Universitaire $\square$

6- Profession : Herboriste $\square$ Cultivateur $\square$ Tradipraticien $\square$ Nomade $\square$ Autres

7- Noms vernaculaires :

\section{II- Espèce végétale et/ou Plante :}

8- Nom scientifique :

9- Type de plante :

Sauvage $\square$ Cultivée $\square$

10- Saison de la récolte :

11- Lieu de récolte :
$\square$ Cours d'eau
$\square$ Montagne
Mare
$\square$ Lacs
$\square$ Autres :

\section{III- Aspect médicinale :}

12- Usages de la plante :

$\square$ Thérapeutique

$\square$ Cosmétique

$\square$ Alimentation humaine

$\square$ Clôture

$\square$ Bois de chauffe

$\square$ Alimentation des animaux

$\square$ Autres :

13- Partie utilisée : Tige $\square$ Fleurs Fruits $\square$ Graine $\square$ Écorce $\square$ Rhizome $\square$ Bulbe $\square \quad$ Feuilles $\square$ Plante entière $\square$ Autres combinaisons $\square$ :

14- Forme d'emploi :

Tisane $\square$ Poudre $\square$ Huiles essentielles $\square$ Huiles grasses $\square$ Extrait (teinture, solution, gélule)

$\square$ Autres $\square$

15- Mode de préparation : 
Infusion $\square$ Décoction $\square$ Macération $\square$ Cataplasme $\square$ Pétrissage $\square$ Ramollissement $\square$ Autre $\square \ldots$

16• Mode d'administration : Oral $\square$ Massage $\square$ Rinçage $\square$ Badigeonnage $\square$ Autres $\square$

17- Dose utilisée :

Pincée $\square$ poignée $\square$ Cuillerée $\square$

Autres :

18- Plantes et/ou autres matières :
$\square$ Aucune
$\square$ Oui

Si Oui, lesquelles?

Notes sur la préparation :

19. Type de maladie :

- Affections dermatologiques $\square$

- Affections respiratoires

- Affections cardio-vasculaires $\square$

- Affections génito-urinaires $\square$
- Affections des tubes digestifs $\square$

- Affections des glandes $\square$

- Annexes du tube digestif $\square$

- Affections neurologiques $\square$

-Autres :

20- Toxicité :

IV-Données socio-économique de Leopoldia comosa $\mathrm{L}$.

21. Nombre ou quantité de la plante récoltée par jour ou par semaine :

22. Nombre ou quantité de la plante déplantée par an :

23. Prix de vente de la matière première par $\mathrm{kg}$ :

24. Types de clients :

25. Demande par les clients :

Fort $\square$ Moyenne $\square$ faible $\square$

Autres

26. Types d'employés :

Hommes $\square$ Femmes $\square$ Enfants $\square$ Indigènes $\square$ Autres

27. Nombres d'employés dans chaque maison :... 
28. Emploi direct :

Temps plein $\square$ Temps partiel $\square$ Autres $\square$

29. Période de travail :

30. Nombre ou quantité de la plante vendues par an :

31. Revenu total par semaine :

32. Prix de revient :

33. Types de commercialisation :

Associations/coopératives $\square$ Intermédiaires $\square$ Souks $\square$ Autres $\square$

34. Evolution de marché :

5. Obstacles que vous rencontrez :

36. Informations supplémentaires : 
ورقة الاستبيان

رقم الإستمارة......

• • المدينة / القرية / الدوار........... •

• - (الباحث

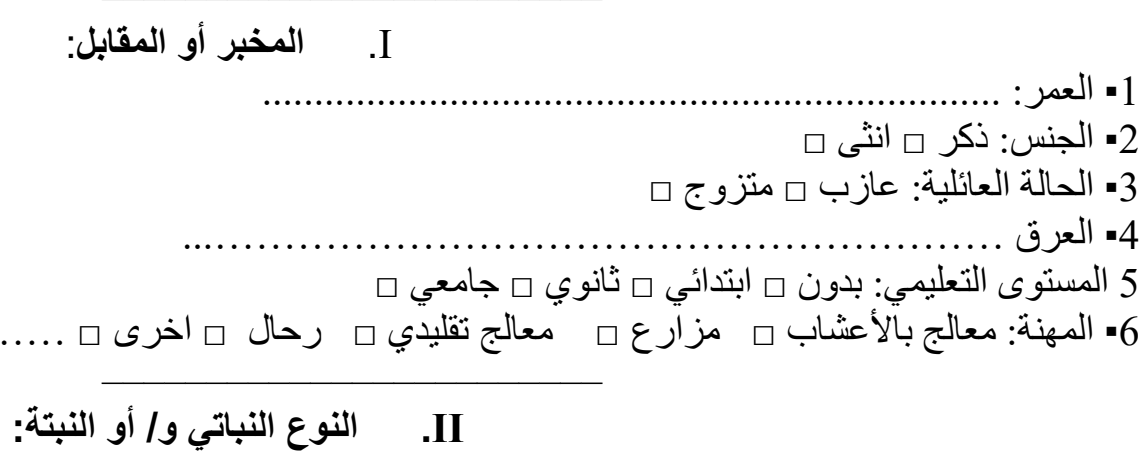

7- الأسماء العامية:

8- الاسم العلمي:

9- نوع النبتة:

برية هـ مزرو عة النية:

10 • موسم الحصاد:

口 بحيرة

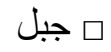

11 - مكان الحصاد:

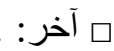

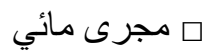

ه بركة او مستنقع ماني

. الجاتب الطبي:
12 - استخدامات النبتة:
口 طبية
口 تغذية بشرية

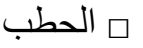
口 أخرى:

口 تجميلية

ه تسييج او سياج

ه أعلاف حيو انية

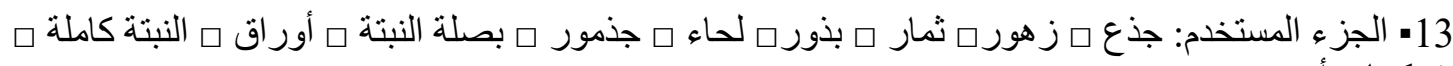

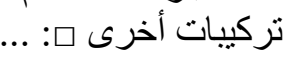
14 - شكل او طريقة الاستعمال:

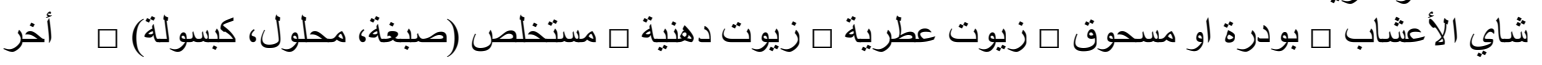




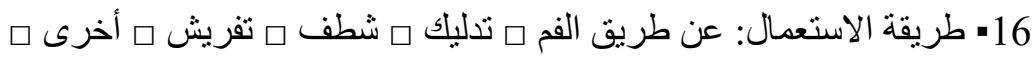

17 - الجر عة المستخدمة:

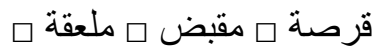

أخرى:.

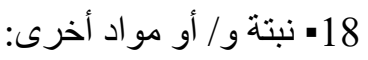

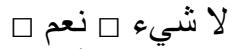

إذا كان الأمر نعم، أذكر ها؟

ملاحظات حول التحضير :

19 - نوع المرض:

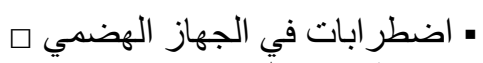

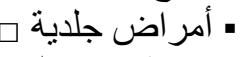

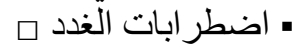

• اضطر ابات الجهاز التنفي

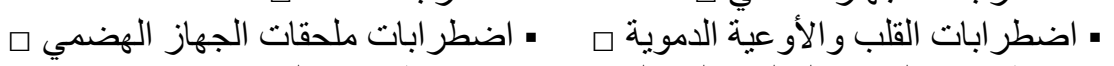

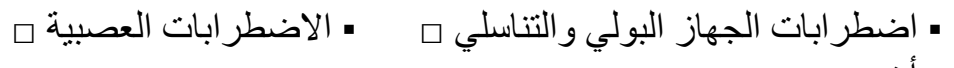

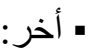

20 - تسمم:

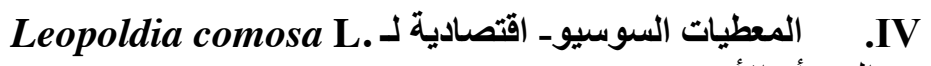

21-عدد أو كمية النبتة المحصودة في اليوم أو الأسبوع:

22-عدد أو كمبة النباتات المنقولة في السنة:

23. سعر بيع المادة الخام بالكيلو جر ام:

24. أنو اع الزبناء:

25. طلب الزبناء:

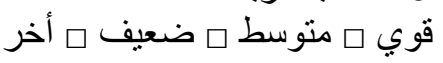

$$
\begin{aligned}
& \text { 26. أنو اع المستخدمين: }
\end{aligned}
$$

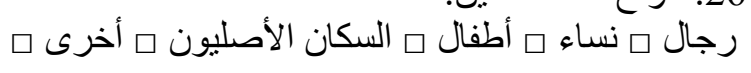

29- فترة العمل:

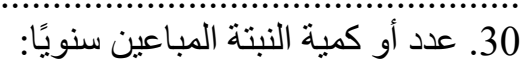




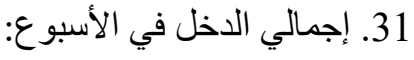
32. سعر التكلفة:

33. أنو اع التسويق:

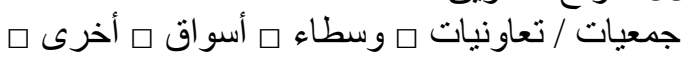
34. نطور السوق:

35. العقبات التي توجهونها:

36- - 5 معلومات إضافية: 